Advances in Geosciences, 5, 75-82, 2005

SRef-ID: $1680-7359 /$ adgeo/2005-5-75

European Geosciences Union

(c) 2005 Author(s). This work is licensed

under a Creative Commons License.

\title{
Quantifying the efficiency of river regulation
}

\author{
R. Rödel and T. Hoffmann \\ Department of Geography and Geology, Jahnstr. 16a, 17489 Greifswald, Germany
}

Received: 7 January 2005 - Revised: 1 August 2005 - Accepted: 1 September 2005 - Published: 16 December 2005

\begin{abstract}
Dam-affected hydrologic time series give rise to uncertainties when they are used for calibrating large-scale hydrologic models or for analysing runoff records. It is therefore necessary to identify and to quantify the impact of impoundments on runoff time series. Two different approaches were employed. The first, classic approach compares the volume of the dams that are located upstream from a station with the annual discharge. The catchment areas of the stations are calculated and then related to geo-referenced dam attributes. The paper introduces a data set of geo-referenced dams linked with 677 gauging stations in Europe.

Second, the intensity of the impoundment impact on runoff times series can be quantified more exactly and directly when long-term runoff records are available. Dams cause a change in the variability of flow regimes. This effect can be measured using the model of linear single storage. The dam-caused storage change $\Delta S$ can be assessed through the volume of the emptying process between two flow regimes. As an example, the storage change $\Delta S$ is calculated for regulated long-term series of the Luleälven in northern Sweden.
\end{abstract}

\section{Introduction}

Runoff time series for a large number of stations are available in global data archives like the GRDC (Global Runoff Data Centre) in Koblenz, Germany, or the NCAR (Bodo, 2005). These data have been used to calibrate and test large-scale watershed models (Alcamo et al., 2003) or to assess the effects of global change (Dettinger and Diaz, 2000).

Many runoff time series are, to some extent, affected by impoundments. Runoff is the cumulate expression of several different processes in a catchment area. Land-use changes, climate changes as well as streamflow regulation all leave their mark on the time series. Water engineering works such

Correspondence to: R. Rödel

(roedel@uni-greifswald.de) as impoundments are one of three dimensions of the human impact on the global water cycle (Vörösmarty et al., 1997; Nilsson et al., 2005). Quantifying the intensity of streamflow regulation is a worthwhile preparation for the assessment of climate and land-use changes (McClelland, Holmes and Peterson, 2004).

The data on the impact of dams and dam cascades on large river catchment areas are scarce. ICOLD compiles statistics on the dams of every country (ICOLD, 1998). From the capacities of 662 geo-referenced reservoirs in a simple digital river network, Vörösmarty et al. (1997) calculated the ratio of the cumulated dam volume to the annual discharge. They included only dams with a gross capacity of more than $0.5 \mathrm{~km}^{3}$. Fiske and Joffe (2001) compiled catchment-related dam statistics. They relied only on dam signatures from digital maps, i.e. the construction years and dam capacities were not included. Nilsson and Reidy et al. (2005) assessed the river channel fragmentation of 292 global catchment areas. In the first step, they delineated the catchment areas. Subsequently, they related them to the dam volumes and compared the gross dam capacity with the annual catchment area discharge.

These studies have clarified the current impact of dams on large river catchment areas. Further research is necessary to be able to quantify the impact of streamflow regulation on any gauging station recorded in global archives like GRDC or NCAR (Bodo, 2005).

\section{Data sets and methods}

\subsection{Dams and impoundments per catchment}

This section describes a method for assessing the intensity of the impoundment impact on European gauging stations. 3410 dams from the ICOLD database (ICOLD, 1998) (Fig. 1) were geo-referenced. Each dam is described by its capacity and the year of construction. The objective was to quantify the impoundment impact on each of 677 European 


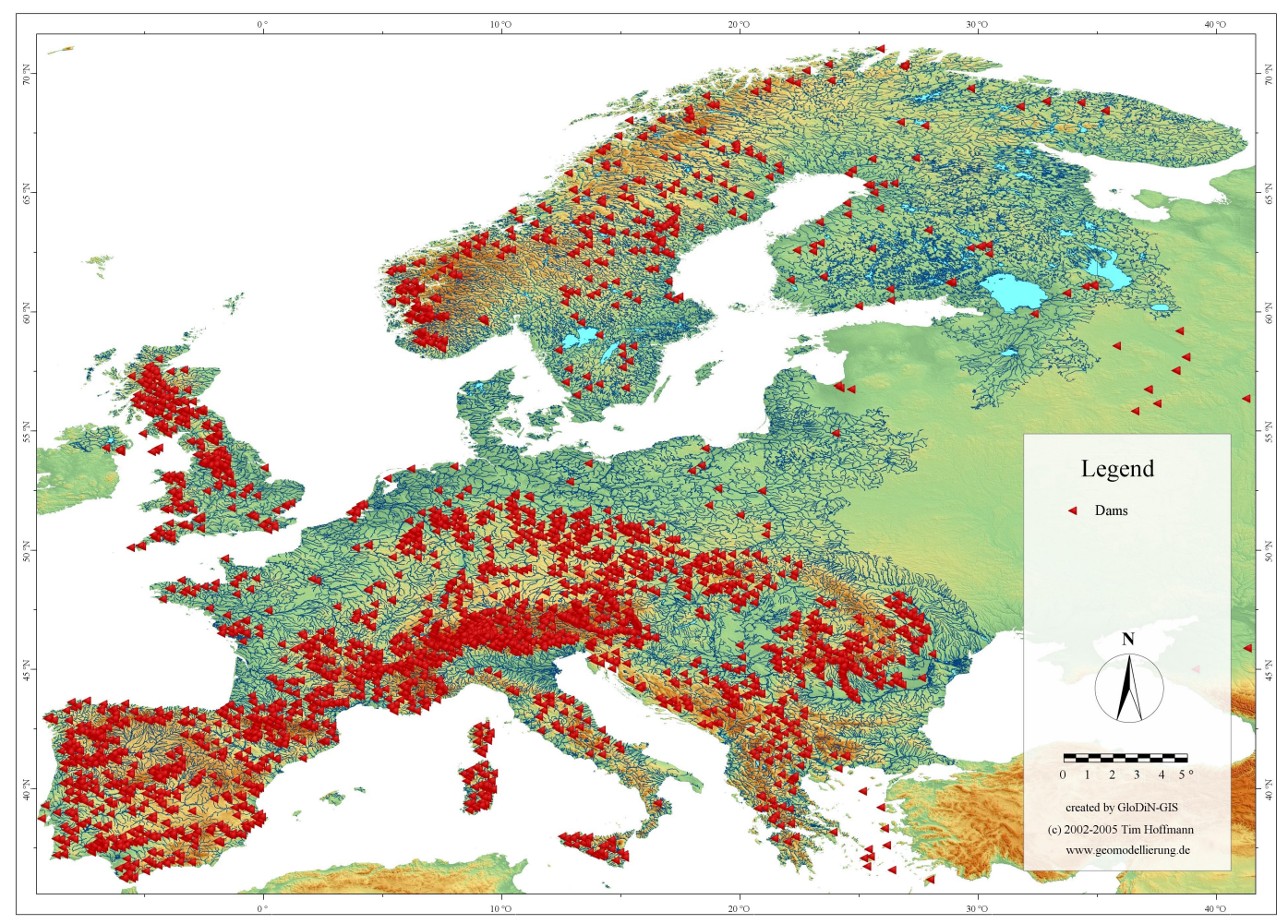

Fig. 1. Dams in Europe (geo-referenced from ICOLD database (ICOLD, 1998)).

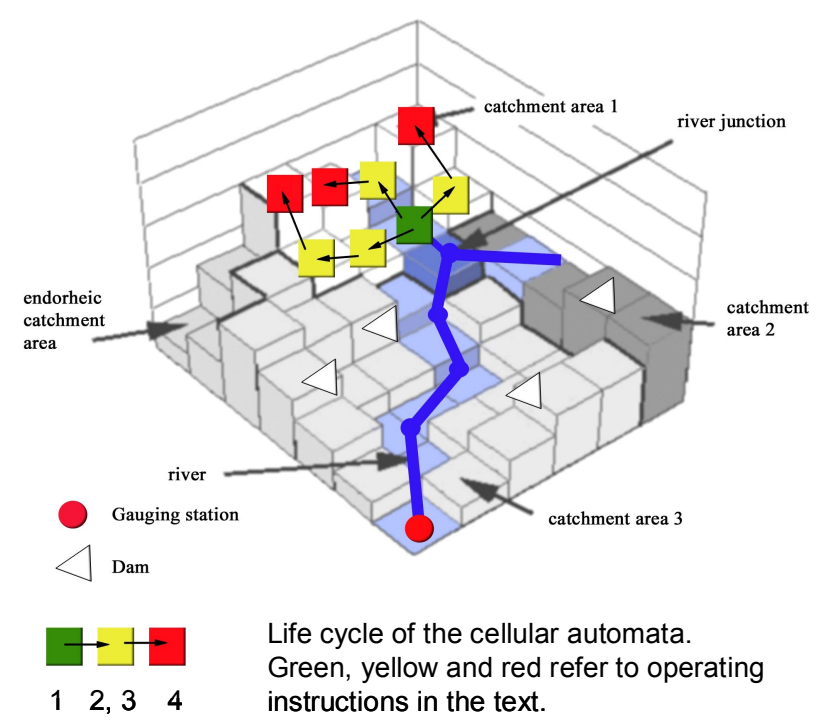

Fig. 2. Generating an upstream catchment area using an additional river layer.

gauging stations from the NCAR and GRDC data archives (Bodo, 2005). In the first step, dams had to be assigned to the catchment area of each station.

The relevant upstream dams and their cumulated capacity were determined for 677 gauging stations (Fig. 6). The impoundment coefficient is the ratio of cumulated upstream dam capacity to annual discharge (Vörösmarty et al., 1997; Nilsson et al., 2005). Since the construction year of each dam is known, impoundment coefficients for different periods can be calculated.

\subsubsection{Derivation of station catchments}

Döll and Lehner (2002) introduced a method for generating a global drainage direction grid with a resolution of $30 \mathrm{~min}$ (DDM 30). The derivation of digital catchments requires a relatively large amount of manual work because the underlying digital elevation model is strongly generalised. For creating a grid with the higher resolution of $30 \mathrm{~s}$ containing global watersheds the method of Döll and Lehner needs a high level of manual corrections. The procedure suggested in this paper highly reduces the manual effort.

The catchment derivation method employed in this study uses a sink-to-source flow algorithm powered by cellular automates which move on the digital elevation model SRTM 30 (2003) by USGS. The starting points of these automates are the geo-referenced positions of digitised rivers and lakes from the hydrologic layer of the DCW (1992) (Fig. 2). This method avoids an important source of error because it does not require calculating the flow concentration along rivers and lakes.

The cellular automates follow the operating instructions (refer to Fig. 2) given below: 
1. (Green) Start at the highest point of the river layer that has not been used as a starting point before! (All points of the river layer will be starting points at one time.)

2. (Yellow) Define the present grid cell as a part of the catchment!

3. (Yellow) Replicate and let your children move to the neighbouring cell if its altitude is higher than that of the present cell (or equal within a fixed radius)! As long as this condition applies, continue with step 2 .

4. (Red) Die if you cannot move on.

5. Select the next starting point from the river layer until you reach the river mouth. Continue with step 1 .

As a result, some grid cells will fail to receive any ID because there is no strictly monotonic rising path that connects them with any of the starting points. The reason, in most cases, is the generalisation of the DEM. Another reason may be that the automates detect apparent endorheic catchment areas. However, because most inland depressions form a part of the river layer, additional, it is unlikely that independent endorheic catchment areas will be discovered. As a consequence, the lowest point of each of these areas should be joined to the adjacent catchment area.

In the next step, the catchment grid areas were vectorised, forming polygons, and the stream network hierarchy was applied. This generation of the order for a stream network contains a smaller manual part as usually and is described in detail in Hoffmann (2004). To validate the algorithm, the documented catchment area sizes of Central European GRDC stations were compared with the calculated values (Fig. 3). This makes it possible to link geo-referenced dams to gauging stations, using a point-in-polygon algorithm.

\subsection{Storage capability of the natural and technical systems}

In addition to the impoundment coefficient, there is a way to assess the human impact on the runoff time series directly. This paper suggests a method that treats flow regimes, which may be changed by impoundments, as results of a linear single storage. Note that this requires long-term discharge time series.

Runoff is an expression of the landscape properties in a catchment area. Therefore, the hydrograph represents these natural and anthropogenic properties as the reaction of a cooperative system. A cooperative system includes the interaction of technical and natural processes and their reflection in the geographical space (Aurada, 2003). Natural and technical storage processes modify the hydrograph, e.g. by redistributing the monthly flows. Technical redistribution usually leads to a smoothed flow regime because the discharge is stored in dams. Therefore, the runoff recorded at a regulation-affected gauging station is a superposition of the variable natural system and the regulated system.

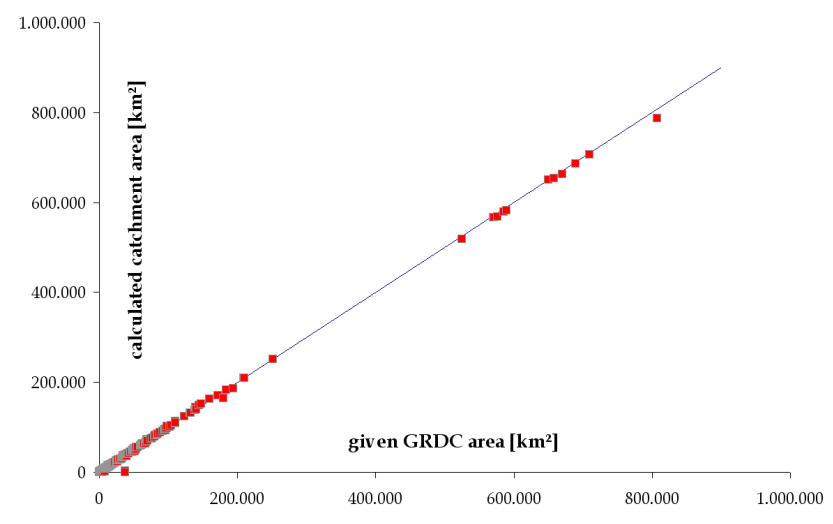

Fig. 3. Validation of calculated area versus documented area of GRDC-stations in Central Europe.

In order to identify runoff changes as signals for changes in the storage systems of a catchment, it is necessary to quantify the changes in both the natural and the technical storages. The technically redistributed volume of a flow regime can be used as an objective criterion to determine the effect of river regulation in a catchment. This volume should be expressed in relation to the potential storage capacity of the dams in a catchment area, and it should be obtained from runoff time series of a gauging station.

Hence, differences between the storage in different years can be expressed as a transformation from a runoff signal of a reference year $\left(Q_{r}\right)$ into the signal of an observed year $\left(Q_{o}\right)$. The reference year is that year in the time series which shows the highest monthly discharge.

Under natural conditions, the year-to-year difference in the volume of the snow cover represents such a change of the storage properties in a catchment. The different shapes of the hydrograph are a result of the different snow volumes or different snow melting in each year. The redistribution of the discharge volume between two corresponding flow regimes $Q_{r}$ and $Q_{o}$ can be understood as storage change $\Delta S$.

The storage change $\Delta S$ can be calculated only after excluding significant trends of the annual discharges. This done, $\Delta S$ can be described as a transformation between the signals $Q_{o}$ and $Q_{r}$ through the emptying process of a linear single storage. To eliminate temporal trends of the annual discharges, the monthly discharges are standardised to the mean of the annual discharges in the time series.

The emptying process of a single storage can be expressed as (from Dyck and Peschke, 1995):

$Q_{o}(m \cdot \Delta t)=\left(1-e^{-\Delta t / K}\right) \cdot \sum_{v=1}^{m} Q_{r} e^{-[(m-v) \Delta t] / K}$

$Q_{o}(m \cdot \Delta t)$ is the outflow at time $t_{m}$. The constant $K$ describes the rate of the emptying process and, as a consequence, the transformation of $Q_{r}$ to $Q_{o}$ in the limits of 1 to $m . m$ is the duration of the emptying process. When $K$ is large, the storage empties rapidly. Contrary a smaller $K$ delays the emptying and results in a smaller emptying rate. 

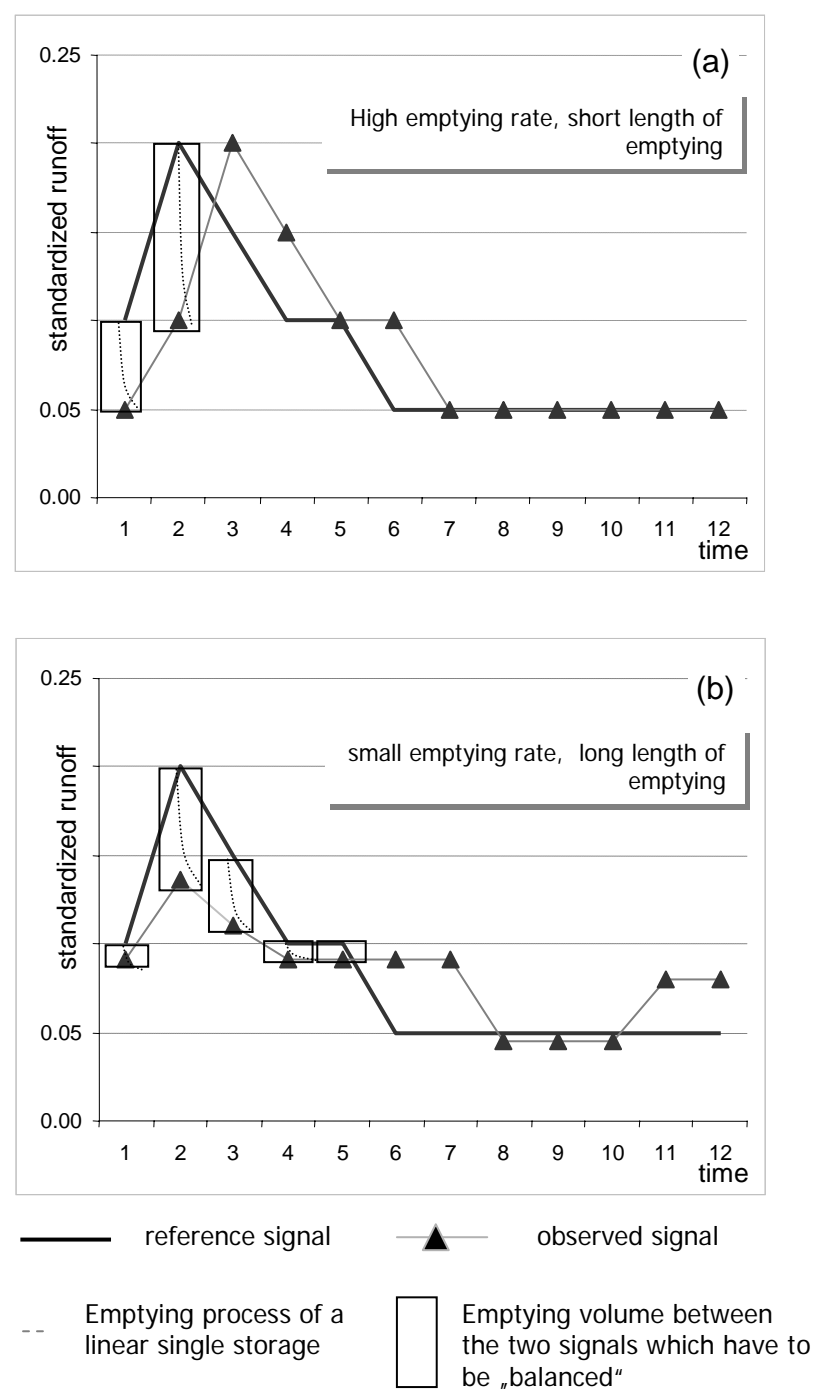

Fig. 4. Transformation between two hydrographs caused by the emptying process of a linear single storage. (a) Transformation of a signal that is shifted forward approximately one time unit. Emptying of the observed signal occurs rapidly. The constant $K$ of this process is estimated as 1.9. (b) Transformation of a smoothed signal. The duration of the emptying process is 5 time units and $K$ is estimated as 1.1 .

Figure 4a shows the integral between the two hydrographs to be compensated. Signal $Q_{o}$ is shifted forward by one time unit, relative to $Q_{r}$. $K$ is high and the storage duration is low, indicating a fast emptying process.

In contrast, Fig. $4 \mathrm{~b}$ visualises the properties of the storage under the influence of river regulation. The peak is smoothed down, and the discharge volume is reduced and distributed over the subsequent months. The storage duration is longer because the emptying process is delayed. Therefore, the storage change $\Delta S$ can be characterised by two properties. First, it is described by the integral of the monthly differences between the regimes $Q_{r}$ and $Q_{o}$ in the limits of the most pronounced emptying process. To identify a significant empty-

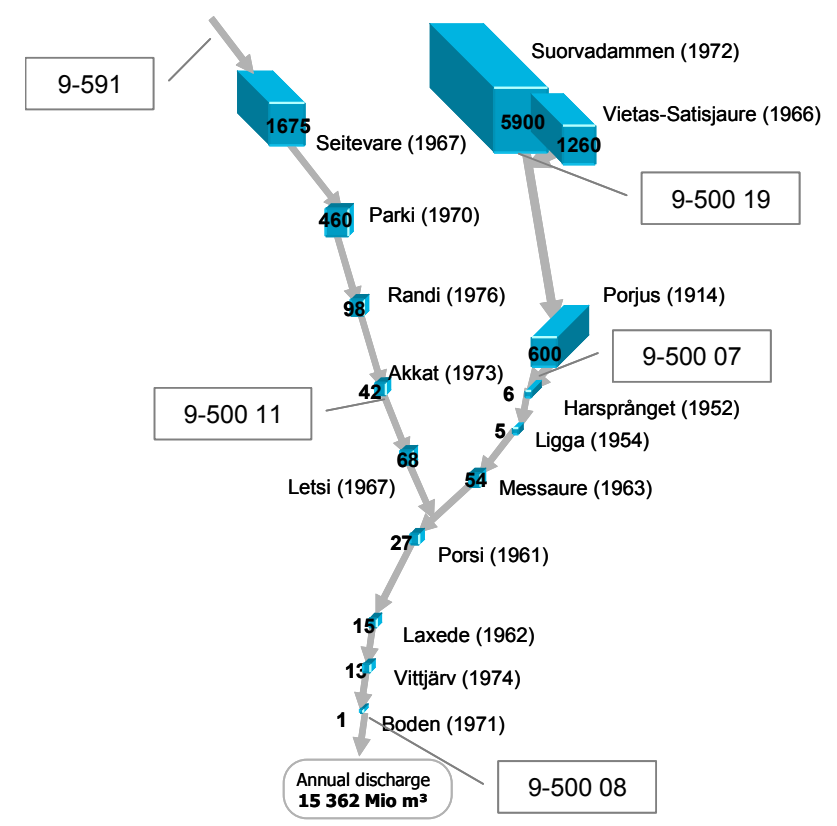

Fig. 5. The dam cascade of the Luleälven River, northern Sweden. The gross dam capacity is given in $10^{-6} \mathrm{~m}^{3}$, along with the year of construction. The small boxes indicate five representative gauging stations for which long-term discharge times series are available.

ing process, it is sufficient to compare successive differences between two hydrographs. These differences must represent the greatest integral of successive differences.

$K$ being the outflow per time unit (i.e. the emptying rate), every positive difference between the discharges is an expression of the current $K$ in $Q_{r}$ and $Q_{o}$. Equation (1) also shows that the duration of the emptying process should also be taken into account. For practical purposes, the duration of the emptying process also provides information on $K$. Technical storage usually leads to a delay of the outflow. The emptying speed is reduced, and $K$ with it, and emptying process takes longer.

Therefore, the duration of the emptying process can be used as an indicator for the transition of $\Delta S$ in case of additional technical storing in the catchment. A storage change $\Delta S$ is indicated by an annually varying storage in the catchment area. Thus, the natural variability of $\Delta S$ can be defined. After the installation of an additional technical storage, $\Delta S$ will usually climb to higher levels. Both the integral of the emptying process for the transformation from $Q_{r}$ to $Q_{o}$ and the duration of the emptying process increase.

To describe $\Delta S$, the integral of the monthly differences between $Q_{r}$ and $Q_{o}$ can be determined in the limits of the emptying process. This integral is labelled $I(\Delta S)$. As in the calculation of the impoundment coefficient, the values of $I(\Delta S)$ can be standardised as volumes using the annual discharges. This approach allows to directly compare the impoundment coefficient, which was derived from the upstream reservoir capacity, with $I(\Delta S)$, which was observed in the discharge records. 


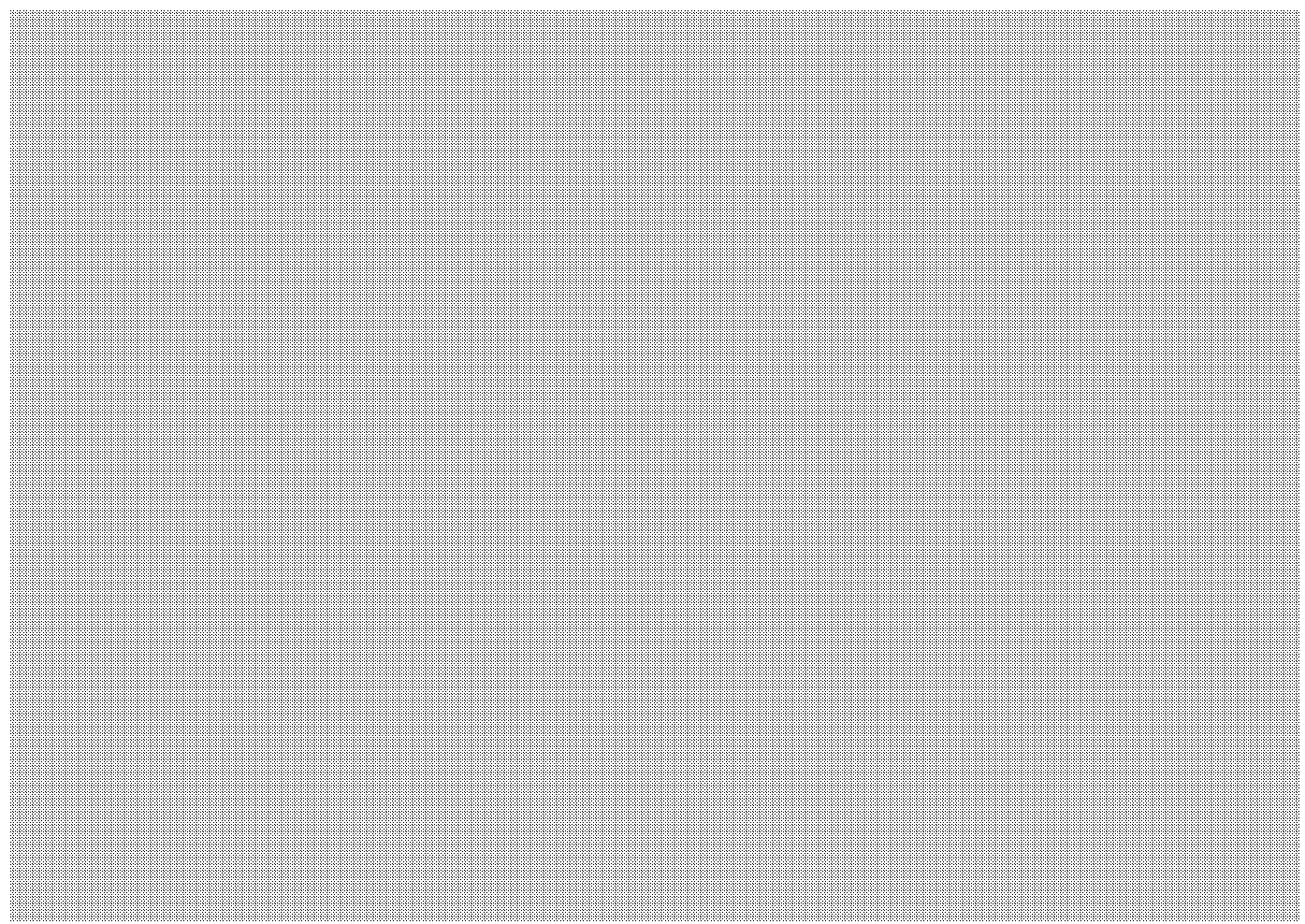

Fig. 6. Impoundment coefficient - i.e. the ratio of the cumulated dam capacity to the average annual discharge of regulated gauging stations - for Europe in 1990.

Figure $4 \mathrm{~b}$ illustrates the effect of the duration of the emptying process. In addition, in the case of similar integral values, this duration also describes the effect of a technical storage. The duration of the emptying process is labelled $D(\Delta S)$. The product of $I(\Delta S)$ and $D(\Delta S)$ can be used as an indicator to better clarify phase transitions to a technical storage.

These methods were used to describe the regulated discharges of the Luleälven in northern Sweden. The catchment area includes several large lakes and many dams which combine to form a storage cascade. The dam cascade serves primarily as a source of hydro-power in the wintertime.

Figure 5 shows the dam cascade as well as the reservoir capacity and construction year of each dam. The storage change $\Delta S$ was calculated for the five gauging stations in Fig. 3, using the respective time series from SMHI (SMHI, 1995).

\section{Results and discussion}

\subsection{Dam capacity per catchment in Europe}

Having determined the catchment areas for 677 gauging stations, it became possible to calculate the cumulated volume of the related upstream dams. Figure 6 presents the dam volume in relation to the annual discharge of the year 1990. This is the impoundment coefficient. At 77 stations $(11 \%)$, the impoundment coefficient exceeds 0.2. It may assumed that these stations are significantly affected by dams. Another
282 stations (42\%), with coefficients between 0 and 0.2 , are affected to a lesser extent.

It should be kept in mind that most of the selected gauging stations represent relatively large catchment areas. In many cases, their annual discharge volume exceeds the upstream reservoir capacity. Moreover, the reservoir capacity as given in the ICOLD database often includes the volume of natural lakes fitted with a dam. For this reason, the impoundment coefficients from Scandinavia appear comparatively high.

\subsection{Efficiency of river regulation (Northern Sweden)}

The integral $I(\Delta S)$ of the gauging stations along the Luleälven River (see Fig. 5) was calculated for each year of the time series. The highest runoff occurred in 1918, making it the reference year $Q_{r}$. The standardised $I(\Delta S)$ curves of the five gauging stations under investigation (Fig. 7) clearly indicate the effect of dams. $\Delta S$ increases in two steps. The small diagram in Fig. 7 shows the natural and the regulated flow regimes of station 9-500 08.

Although dam construction in this catchment area began early, $I(\Delta S)$ leaps to a higher level only in 1940 . Obviously, there was no dam construction at the upstream branches during the initial phase of lake management. The second significant increase occurs only in 1970 and is clearly related to the contemporaneous increase of the impoundment coefficient.

The average discharge volume redistributed by the technical storage system is expressed by the difference between 
Table 1. Mean $I(\Delta S)$ at gauging stations of the Luleälven River during each of three regulation periods. The values of stations 9-591 and 9-500 11 during periods 1 and 2 are identical on the 99-percent significance level ( $t$ test).

\begin{tabular}{lccccc}
\hline $\begin{array}{l}\text { Gauging station/ } \\
\text { Mean storage capability }\end{array}$ & $\begin{array}{c}9-591 \\
\text { (unregulated) }\end{array}$ & $\begin{array}{c}9-50019 \\
\text { (regulated since 1922) }\end{array}$ & $\begin{array}{c}9-50007 \\
\text { (regulated since 1922) }\end{array}$ & $\begin{array}{c}9-50011 \\
\text { (regulated since 1967) }\end{array}$ & $\begin{array}{c}9-50008 \\
\text { (regulated since 1922) }\end{array}$ \\
\hline $\begin{array}{l}\text { period 1 (1900-1940) } \\
\text { mainly unregulated } \\
\text { period 2 (1941-1970) }\end{array}$ & 0.23 & 0.17 & 0.14 & 0.18 & 0.11 \\
$\begin{array}{l}\text { regulated in upper } \\
\begin{array}{l}\text { Stora Luleälven } \\
\text { period 3 (1971-1990) } \\
\text { mainly regulated }\end{array}\end{array}$ & 0.20 & 0.46 & 0.34 & 0.19 & 0.22 \\
\hline
\end{tabular}

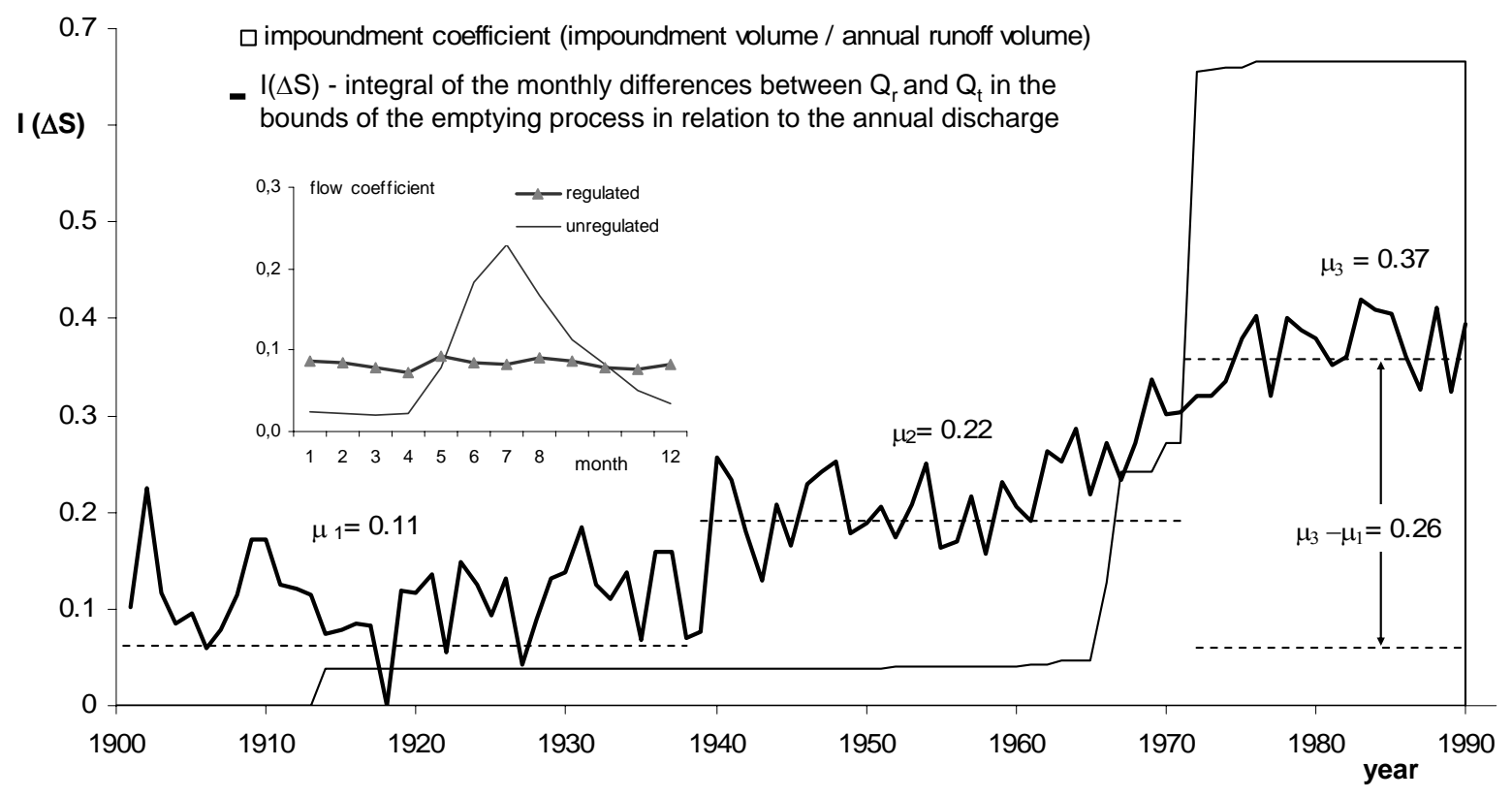

Fig. 7. Impoundment coefficient and standardised $I(\Delta S)$ in the natural system $(\mu 1)$ and under regulation $(\mu 2$ to $\mu 3)$. Station 9-500 08, Boden, Luleälven, northern Sweden. Small diagram: natural and regulated flow regimes.

the means of $I(\Delta S)$ during the two periods 1970 to 1990 and 1900 to $1940\left(\mu_{3}-\mu_{1}\right.$ in Fig. 7). Note that standardised $I(\Delta S)$ values were used. The difference $\mu_{3}-\mu_{1}$ amounts to 0.25 , i.e. a quarter of the annual runoff is redistributed because of the dam cascade. The efficiency of the dam cascade is the ratio of this storage potential, assessed through the runoff record, to the impoundment coefficient, which was derived from the gross capacity of the dam cascade. The dam efficiency at the Luleälven in the period from 1970 to 1990 is 0.38 , i.e. the impoundments actually utilise $38 \%$ of the gross dam capacity for river regulation.

Figure 8 shows the development of $I(\Delta S)$ at the individual gauging stations along the dam cascade. Station 9-500 19 is located at the upper branches of the Luleälven. According to ICOLD (1998), it has been affected by regulation only since the construction of the Suorvadammen in 1972. However, the hydrologic yearbooks (SMHI, 1995) indicate a regulation impact since 1922. In Fig. 8, however, this effect can be recognized by higher values of $I(\Delta S)$ only since about 1940 . The outflows of the lake Stora Lulevatten upstream station 950019 are therefore regulated considerably since the year 1940.

The records from station 9-500 07 support this view. Although there was an upstream dam since $1914, I(\Delta S)$ increases only in 1940. The impact of the upstream station 9-500 19 is also visible. The pre-1967 record from station 9-500 08 represents the natural variability of $I(\Delta S)$. The increase around 1967 corresponds to the construction of upstream dams at that time. As a reference, the values of the completely non-regulated station 9-591 are also given.

Three different $I(\Delta S)$ levels are discernible in Fig. 8. They reflect different intensities of the river discharge regulation. Table 1 gives the (standardised) average values of $I(\Delta S)$ for each station during each of the three periods. The dam-induced increase of $I(\Delta S)$ can be estimated from the difference between the means of periods 2 or 3 and period 


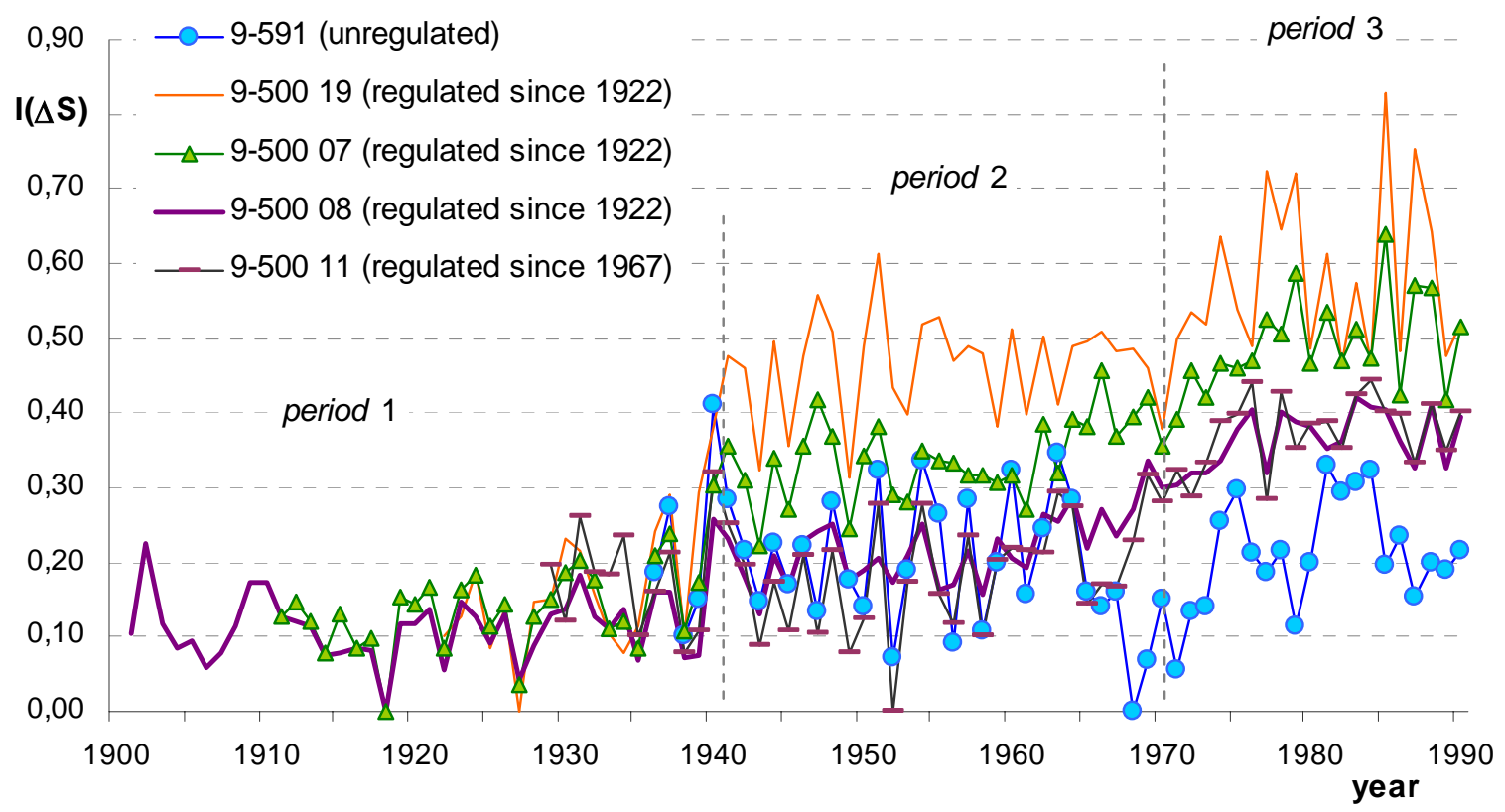

Fig. 8. $I(\Delta S)$ along the dam cascade of the Luleälven River. There is little or no regulation during period 1, regulation at the upper reaches during period 2 (stations 9-500 19 and 9-500 07), and general regulation during period 3. See Table 1 for the average $I(\Delta S$ ) values during each period.

1. The result can be directly compared to the impoundment coefficient (see Sect. 2.2).

It now becomes clear that station 9-591 is unaffected by regulation. The discharges of station 9-500 11 are affected only during period 3. Stations 9-500 19 and 9-500 07 show the strongest regulation impact, which decreases towards the mouth of the Luleälven River. Here, at station 9-500 08, the mean $I(\Delta S)$ during periods 1 and 3 is lower than at stations 9-500 19 and 9-500 07.

\section{Summary and conclusions}

The objective of this study was to develop methods for quantifying the intensity of river regulation using global runoff records. Two different approaches were introduced and discussed. In the first, established approach (Vörösmarty et al., 1997), the upstream dam volume is compared with the upstream volume of the annual discharge and calculated the impoundment coefficient. This requires that the catchment area of the station be determined. One way to do this is to relate the upstream storage capacity to individual gauging stations using geo-referenced dam statistics. The authors generated a geo-referenced data set of European dams and used a sinkto-source flow algorithm to link dams to gauging stations. Subsequently, the impoundment coefficients were calculated for 677 stations in Europe.

The second, new approach assesses the effects of river regulation directly from hydrologic records. It measures the actually stored discharge volume $\Delta S$, as compared to a reference hydrograph. The impoundment coefficient indicates the potential volume of the technical storage systems. The storage change $\Delta S$, in contrast, measures the actually observable effect of river regulation. The impoundment coefficient should be used if the time series reflecting river regulation is rather short. The $\Delta S$ approach requires long-term discharge records, or records extended using appropriate methods.

Edited by: P. Krause, K. Bongartz, and W.-A. Flügel

Reviewed by: anonymous referees

\section{References}

Alcamo, J., Döll, P., Henrichs, T., et al.: Development and testing of the WaterGAP 2 global model of water use and availability, Hydrological Sciences Journal - Journal des Sciences Hydrologiques, 48 (3), 317-337, 2003.

Aurada, K. D.: Co-evolvierende + co-respondierende Systeme = co-operierendes System, Erdkunde, 57/ 4, 309-330, 2003.

Bodo, B.: Monthly Discharge Data for World Rivers, http://dss. ucar.edu/datasets/ds552.1/, date of access: 7.1.2005.

DCW: Digital Charts of the World, Server: http://www.maproom. psu.edu/dcw, date of access: 7.1.2005.

Dettinger, M. D. and Diaz, H. F.: Global Characteristics of Stream Flow Seasonality and Variability, J. Hydrometeor., 8 (1), 289310, 2000.

Döll, P. and Lehner, B.: Validation of a new global 30-min drainage direction map, J. Hydrol., 258, 214-231, 2002.

Dyck, S. and Peschke, G.: Grundlagen der Hydrologie, Berlin, Verlag für Bauwesen, 1995.

Fiske, G. and Yoffe, S.: Use of GIS for analysis of indicators of conflict and cooperation over international freshwater resources, http://www.transboundarywaters.orst.edu/publications/, date of access: 7.1.2005, 2001. 
ICOLD: World Register of Dams = Registre mondial des barrages, International Commission on Large Dams, Paris, 1984 and 1998. GRDC: The Global Runoff Data Centre, D-56002 Koblenz, Germany, http://grdc.bafg.de/, date of access: 7.1.2005.

Hoffmann, T.: Automatenbasierte Korrektur und Bearbeitung digitaler Gewässernetzgraphen, in: Angewandte Geoinformatik 2004, edited by: Strobl, J., Blaschke, T., and Griesebner, G., Wichmann, Heidelberg, 243-248, 2004.

McClelland, J. W., Holmes, R. M., and Peterson, B. J.: Increasing river discharge in the Eurasian Arctic: Consideration of dams, permafrost thaw, and fires as potential agents of change, J. Geophys. Res., 109, 1-12, 2004.
Nilsson, C., Reidy, C. A., Dynesius, M., and Revenga, C.: Fragmentation and flow regulation of the world's large river systems, Science, 308 (5720), 405-408, 2005.

SMHI: Vattenföring i Sverige Del. 1. Vattendrag till Bottenviken, Norrköping, 1995.

SRTM30: Shuttle Radar Topography Mission, Server: ftp: //edcsgs9.cr.usgs.gov/pub/data/srtm/SRTM30, date of access: 7.1.2005.

Vörösmarty, C. J., Sherma, K. P., and Fekete, B. M., et al.: The Storage and Aging of Continental Runoff in Large Reservoir Systems of the World, AMBIO 6/1997, 210-219, 1997. 